\title{
Utilization of simple presentation methods for comparative studies in the historical mining
}

Wykorzystanie metod prostej prezentacji w studiach porównawczych historii górnictwa

\author{
Pavol Rybár, Mário Molokáč, Ladislav Hvizdák, Jana Hvizdáková \\ Technical University of Košice, Institute of Geotourism, \\ Letná 9, 04200 Košice, Slovakia; \\ e-mails:pavol.rybar@tuke.sk,mario.molokac@tuke.sk,ladislav.hvizdak@tuke.sk,jana.hvizdakova@tuke.sk
}
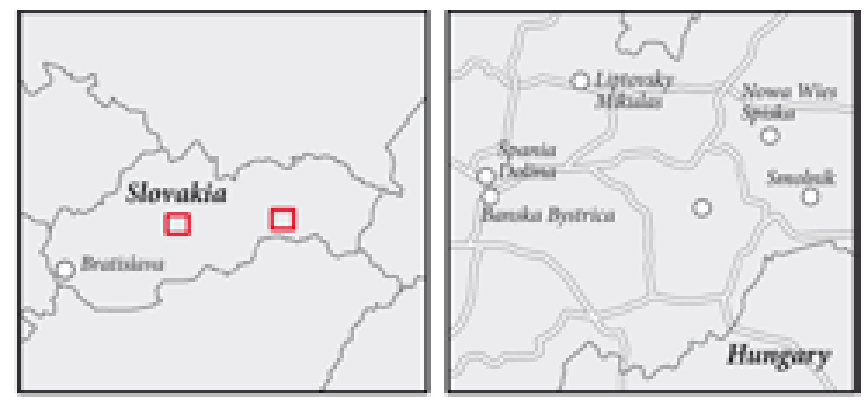

Abstract: The article deals with two important sites of the copper cementation process in historical mine deposits, namely Spania Dolina and Smolnik in Slovakia. It analyzes these two historical mining sites from several points of view, such as their significance at the time, applied technologies and philosophers interested on it. For comparison, simple presentation methods were used based on graphic and animation software. The methods show historical mining in a broader context making it possible to combine its developments with other historical facts. The paper used presentation methods for comparing technologies and knowledge about cementation waters in two Slovak historical mining locations Smolnik and Spania Dolina.

Key words: Smolnik, Spania Dolina, cementation water, historical mining, transmutation of metals, visits of distinguished persons, new methods of presentation on timeline

Treść: Artykut przedstawia dwa ważne, historyczne ośrodki górnictwa rud metali: Dolinę Szpania i Smolnik na Stowacji, w których zastosowano cementacyjna metodę odzysku miedzi. Oba ośrodki historycznego górnictwa analizowano z różnych punktów widzenia, np. ze względu na ich znaczenie w porzadku chronologicznym, zastosowane technologie i zainteresowanie ze strony uczonych filozofów. Do celów porównawczych zastosowano metody prostej prezentacji oparte na oprogramowaniu graficznym i animacyjnym. Takie metody pozwolity na ukazanie historycznego górnictwa rud w szerszym kontekście, tak by połaczyć opis jego rozwoju z innymi faktami historycznymi. Zastosowano metody prezentacyjne do porównania technologii $i$ wiedzy na temat roztworów cementacyjnych $w$ obu stowackich historycznych okręgach górniczych: Smolniku i Dolinie Szpaniej.

Stowa kluczowe: Smolnik, Dolina Szpania, roztwory cementacyjne, historyczne górnictwo, transmutacja metali, wizyty wybitnych osobistości, nowe metody prezentacji faktów w porzadku chronologicznym

\section{Introduction}

A comparison of events in the form of texts describing that, for example, in two different places, or at two time intervals is the most common method used. Description of the same events in two different locations gives a good picture of what it was before, which was more perfect, in what were the differences, and the like. There are other usable comparison methods e.g. documentation of different maps (Weis \& Nagy, 2009), data or documents, other historical materials. All of them provide an illustrative view of the assessment of the status, namely conformity or difference in the details, or the whole. Often we can see, especially in specialized journals, co-static viewing as a static displayed timeline and events that occurred at that time (Fig. 1). Nowadays, similar localities are the subject of interest of many researchers, not only in the field of historical mining (e.g. Drebenstedt et al., 2011; Herčko, 2003a,b; Hronček et al., 2009; Rybár et al., 2012). Providing just such a simple display helps one to understand the logic and sequence of events.

The current IT technologies make it possible to use a desktop screen, projection screen, or other IT environment, which (in which) it is possible to project the image and text data showing the same event or activity in the dynamics of the current time.

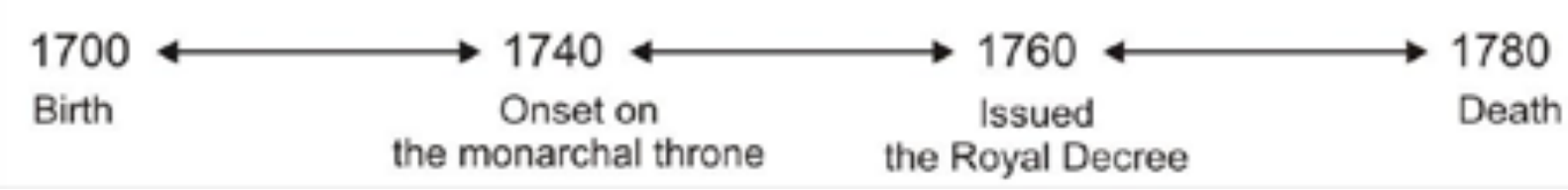

Fig. 1. Static display events using the timeline • Najważniejsze wydarzenia w porządku chronologicznym 


\section{Description of the method used}

Let us divide the monitor screen into a few horizontal strips. The number of strips corresponds to the number of events displayed. One strip will always show the passage of time. For example, when comparing one historical activity and its evolution in two different locations, we divide the display screen into three horizontal strips. The first, as already mentioned, will display the timeline, the other will represent the development and use of technology in the area A. The third strip will show development of using the same technology in area $\mathrm{B}$.

If someone would like to 'see' the historical mining in the wider context, it is possible to divide the screen into more horizontal strips. Limiting is the visibility of simultaneously displaying data. The object of the study may be, for instance, the impact of historical events on the development of the mining town, a mining region, state formation, or otherwise - as chosen by the author of the study in the established region. Such historical events may be, for example, economic development, technological development, acts of war, natural disaster, plague events, cultural expansion and the influence of the church.

\section{Applied technologies}

To view the various historical events, it is necessary to choose suitable presentation software. Currently, information technologies offer a number of software applications, and one need to choose the best one which displays the required information most appropriately (Rybár, Hvizdák, 2010; Hvizdák, 2013).

To display the timeline and other selected events requires the selection of suitable graphic software, like CorelDraw, which enables a combination of text, images and detailed arrangements in the timeline. Another advantage of the graphic software is that one can use it to create time lines long enough, for example for several centuries as well as a sufficient amount of assigned events and several horizontal strips. The graphic representation thus reveals the relationship between the different strips at a time.

For the presentation of achieved results, it is appropriate to use presentation software such as PowerPoint, which makes it possible to present the graphic display in a static form. If the time axis is long enough, for a presentation is possible to use animation. Animation of historical events displayed on the common time line helps to create a new understanding of historical events developed in different places at the same time.

\section{The cementation of copper in the historical Slovak deposits - a case study}

Occurrence of cementation water at Spania Dolina and Smolnik, which were for centuries marked as a Hungarian curiosity, was the object of attention for both national and foreign alchemists, chemiatrists, mineralogists and natural scientists. The specific characteristics of both deposits, Smolnik and Spania Dolina, led to the capacity to obtain copper from cementation waters. This way, the acquisition of copper was accomplished with precipitation by means of iron.

Ideas about this long time mysterious process for obtaining copper by means of iron, lead alchemists to assume that this takes place by confirmation of the transmutation of the lower metal - iron, onto the higher one - copper.

However, many experts of 17 th Century refused to accept the previous explanation that this represented a true transmutation of iron into copper. When iron is apparently transformed into copper via this process, many particles are isolated and gather on the bottom of the cementation water in a powder form. This material is not, however, iron, but instead copper. Dr. Brown was able to extract this powder from the water and melt it into excellent copper (Herčko et al., 2014).

\section{Historical scientific works on cementation, or the transformation of iron onto copper and occurrence of miraculous waters in the Hungarian Kingdom}

Cementation waters in Hungarian (Slovak) copper deposits were presented in works of alchemists, polymaths, doctors and natural scientists already from 16th century. Smolnik' and Spania Dolina' cementation waters were known, because copper from Smolnik was exported to Poland, Prussia, and from there, to other northern and western countries of Europe. Copper from Banska Bystrica and its vicinity was exported to southern European countries.

\section{Smolnik}

Smolnik cementation waters were described in historical scientific works as early as in the 16 th century. Pseudo-Basilia Valentín mentioned this phenomenon in the vicinity of Smolnik and presented it as example of the transmutation of metals. In the years 1526 and 1527 respectively, miraculous waters in Smolnik were visited by the famous humanist Theophrastus Paracelsus (1493-1541). He described Smolnik cementation waters in the Spis area in his work Dietinctura physicorum. In a part dealing with solutions, he wrote about the cementation waters and called them 'Zipser brunnen'. Paracelsus (Tab. 1) considered the precipitation of copper by an iron like confirmation of the transmutation of elements.

The royal counsellor of the Spiš chamber and Captain of Saris Castle, Juraj Wehrner, was one of the first who introduced to the European scientific public the chalcopyrite stream at Smolnik, and the possibility 'to change' iron to copper in his work De admirandis. Hungariac aquis hyppomnemation, published in 1542 in Basel (Herčko et al., 2014). He described the process of copper extraction from the waters of Smolnik with the assistance of embedded iron objects. The settled mass contained a copper, called by miners as 'cement'. This apparent transmuting ability of cementation 
water, Wehrrner noted, is due to markazite (pyrite) contained in the cementation water. The alchemists sought evidence that Nature could extract copper directly from iron, thus producing one metal from another (Herčko et al., 2014).

Tab. 1. Famous scholars in Smolník and Spania Dolina • Sławne osobistości przebywające w Smolniku i Dolinie Szpaniej

\begin{tabular}{|c|c|c|}
\hline $\begin{array}{l}\text { Year } \\
\text { Rok }\end{array}$ & Smolnik & Špania Dolina \\
\hline 1521 & - & Theophrast Paracelsus \\
\hline $1526-27$ & Theophrast Paracelsus & - \\
\hline 1528 & Ján Dernschwamm & - \\
\hline 1542 & Juraj Wehrmer & - \\
\hline 1563 & Ondrej Smoczký & - \\
\hline 1566 & $\begin{array}{c}\text { Members of the } \\
\text { Commission of Royal } \\
\text { Chamber }\end{array}$ & - \\
\hline 1639 & Dávid Fröhlich & - \\
\hline $1629-57$ & Daniel Geyer & - \\
\hline 1664 & Štefan Thököly & - \\
\hline 1672 & - & E. Brown \\
\hline 1696 & $\begin{array}{c}\text { Alfonz Ferdinand } \\
\text { Marsigli }\end{array}$ & $\begin{array}{c}\text { Alfonz Ferdinand } \\
\text { Marsigli }\end{array}$ \\
\hline 1724 & $\begin{array}{l}\text { František Ernest } \\
\text { Brückmann }\end{array}$ & - \\
\hline 1730 & Ján Juraj Keysser & - \\
\hline
\end{tabular}

The cementation waters of the mines of Smolnik and the process of cementation were of interest for the alchemist A. Smoczky. In his manuscript Vade mecum et ego tecum from the year 1563, he declared the process of cementation like an example of the transmutation of iron into copper. The process of obtaining of copper, he wrote, took place when the cementation waters were obtained by pumping from the mine, and when putting pieces of iron into the water, those changed onto the copper. If these iron pieces are slim, they are covered by copper and by smelting them in fire, one can obtain copper. He saw this transmutation with his own eyes, when he visited the Smolnik' mines. This whole process, he understood in the sense of mediaeval alchemy.

The Smolnik cementation waters were referred to at the same time by the known geographer and astronomer, editor of almanacs Dávid Fröhlich (1595-1678) from Kežmarok in his work Medulla geographiae practicae peregrinantium imprimis usui. He was the first author from the Spis region who mentioned that in Smolnik copper the transmutation of iron is achieved.

In the year 1664, the Saxony prince Ernest asked earl Štefan Thököly to investigate the effect of transformation of iron into copper, with the help of vitriol waters in Smolnik. In the answer, Earl Thököly described in detail the manner of obtaining copper from cementation waters through the medium of iron. His answers were exhibited in the Saxony museum of curiosities.

In addition, G.W. Wedelius published his answer in the journal Ephemeri des naturae curiosum (1656-1676), under the name Descriptio, qualiter ferrum mutetur in cuprum in Smolnick.

Daniel Geyer, a physician in Bratislava in the years 1629 and 1657 respectively, dealt with Smolnik's cementation waters. The majority of contemporary scholars and alchemists, such as J.J. Becher and G. Wedel interpreted cementation waters as a natural miracle.

The next author, who was interested in Smolnik' cementation waters was German polymath Ján Juraj Keyssler (16841743). His observations of Slovakia were described in the second part of his work Neuester Reisen durch Deutschland, Böhmen, Ungarn, die Schweitz, Italien und Lothringen (Hannover).

\section{Distinguished visits in Smolnik and their works in connection with the process of cementation}

In the year 1528, Ján Dernschwamm, employed by the Thurso/Fugger society, factory of the Banska Bystrica'copper mine, visited the Smolnik' copper mines. He was accompanied by Matej Pribitzer and another unknown Hungarian noble, sent by Thurzo. In the report, it is also mentioned that the Košice' townsman family Sauer, produced copper by the process of cementation in Smolnik.

According to the report, copper was gathered by the classical mining methods as well as by the process of cementation, mentioned already in the old deed from the year 1497. The cementation itself was the subject of interest from the point of view of technological development for the preparation of ores in Slovakia. According to the Derschwam's report, it was an inexplicable process, not managed during these times by European scholars, and that's why it invited the attention of scholars from all over the world.

The Sauer family owned a pumping device and paid to miners $1 / 7$ th from the mined ore for exhausted water from the mines. The Sauer family produced copper by the sinking of scrap iron onto cementation waters. They used feed tanks, in which they put as much as 3,000-3,500 cents (pounds) of iron, respectively. In this way, they produced as much as 400 cents of copper per year. The prodictivity was 3 cents of copper from every 4 cents of iron. In the case of a lesser concentration of water (rainy weather), they produced 4 cents of copper from 5 cents of iron. The Sauer family produced 600 cents of 'vitriol' water per year.

From the year 1566, the technology of processing copper was recognized in written form. Mined pyrites were compacted and then smelted in a furnace, which took one week. Then, blister copper was transported to Levoča, where it was processed and refined into forms of pure copper. From these times, the technology of cementation water acquisition was known. On a dike zone, digged holes, which miners filled by water, were found. Then, water was pumped into wooden canals, bedded by pieces of iron. The coagulation of copper 
and iron was picked up once during two-three weeks and was transported to the smelting house.

The rulers as well as professional society took an interest in the cementation waters of Slovakia in the 17 th century. Its mysteries were of interest to the eminent scientific authority Isaac Newton, secretary of the Royal Society in London. A letter, written in 1667 to Cambridge Aston contained detailed instructions as to what to look for on foreign trips. He was interested in conditions in the Hungary Kingdom and was looking for the explanation of whether iron was transformed to copper by the vitriol waters found there in the rocks, and whether this copper could then be melted to appear after cooling.

Because of the process of cementation in Smolnik, water was sucked from underground works, or water was enriched by copper passing through large waste piles. Then, such enriched water was driven through a number of trenches, where iron scraps were deposited. Iron was corroded and 'melted' into pure copper. In the beginning of the 18th century $30 \mathrm{t}$ of copper were produced in this way, whereas one century later, about $100 \mathrm{t}$ of high-grade copper were made by this technology.

Besides the cementation and compaction used in Smolnik, there was a third mode of extracting copper. It was based on the extraction of pyrite ores laid on the layer of firewood. At the top of the pile, melted sulfur was subsequently sapped. The melted ore was then fed water which reacted with sulfur to make sulfuric acid. Finally, the copper was bound with each. The obtained cementation water was then processed by conventional means.

Earl A.F. Marsigli, a member of the Paris, London and Montpelier Royal Societies, visited Špania Dolina in 1696 and also his attention was drawn to cementation waters. His knowledge was published in a six-volume work Danubius Pannonico-Mysicus, observationibus geographicis astronomicis, hydrographicis, historicis, physicis, perlustratus et in sex tomos digestus. The complex work was published in 1726 in Amsterdam and was devoted to geographical, historical and geological sciences in Danubian Panonia. In the third volume, there is a part on Smolnik'coper mines and cementation waters. Marsigli explained the transformation of iron to copper. He argued that there were three streams of cementation water which flowed from the surface to underground where they collected in pools. Iron there was slowly covered by copper powder, which was secreted from the cementation water.

A famous German scholar, Doctor of Medicine, František Ernest Brückmann, the member of Imperial Academy of natural specialties, and member of Royal Prussian society of science, traveled in 1724 through the Spis region. His way passed through Liptovský Mikuláš, Kežmarok, Levoča, Spišská Nová Ves, Dobšiná, Rožňava and Smolník to Prešov. His observations have been summarized in the work issued in a comprehensive work Magnalia dei in locis subterraneis, edited at Brainschweig in the year 1727.

In the introduction of the work F.E. Brückmann described Smolnik' copper mines and cementation waters. He stated that mines produced 7,000 cents of pure copper. Cementation water was pumping by the help of pumping devices placed on the surface as well as underground. Water flowed through more than 300 trenches full of pieces of waste iron. Water corroded iron and by precipitation pure copper was produced.

F.E. Brückmann, in the second edition of his work, called attention to other works dealing with Smolnik: D. Froelichius in Bibliotheca peregrinantium, G. Agricola citated by Cardan in Subtilis liber, father Gabriel Rzaczyński in Historia naturalis Curiosities Regni Poloniae and Johann Melchior Verdries in Resp. De Cupri origine, tractatione et usibus.

Work of Krištof Andrej Schlüter Gründlicher Unterricht von Hütte-Werken..., published at Braunschweigu in the year 1738 , was a contemporary work with F.E. Brückmann. Reports, technological characteristics and schemes of the Slovak smelters were acquired from his nephew Krištof František Seidensticker, who visited these smelters in years 1722 and 1723, respectively of 144 chapters, 13 deal with smelters and metallurgy in Slovakia. Other data concerning Slovak smelters are scattered in other chapters of Probierbuch. Special care is given to the mining of copper by cementation at Smolnik and Spania Dolina.

In June 1793, two students from Budapest University, Dominik Teleki and Horváth visited Smolnik. They described the copper mines and especially the extraordinary machines used there for pumping water and transporting ore on the surface. Machines were powered by wheels with diameter as much as 6-7 fathoms (siaha). Running down water from Smolnik' hills contained cementation copper and chalcopyrite, as the ore which was mined there.

\section{Spania Dolina}

The young English doctor Edward Brown visited Spania Dolina at the behest of the Royal Educational Society in 1672. In his report from Spania Dolina he described two springs of vitriol water which changed pieces of scrap iron to copper, calling them new and old cement. The springs rose deeply in the mines, and the iron was in general submerged for 14 days. These waters were extremely valuable as the lowest grade of iron, including scrap could be changed into pure copper, which was even more malleable and easier to melt than copper ore. Dr. Brown also found that this metal could be melted without the addition of other elements, while copper ore required several re-meltings to become usable. In one experiment, he immersed an iron ingot in the shape of a heart in the water for about 2 weeks. It retained its original shape, but all iron was replaced by copper (Herčko et al., 2014).

In the Spania Dolina mines, Dr. Brown observed 'two springs with vitriol water' and accepted the traditional opinion that this represented a transmutation of a lower metal to the higher one - iron to copper. Anyway, he was attentive to the other scientist's ideas. The latter believed that the springs were composed of a copper sulphate solution (Vitriolum von Kupfer), parts of which are deposited in copper form in immersed iron. This opinion correctly describes the gist of the cementation process. He also addressed the questions put by Isaac Newton to Cambridge Aston regarding the vitriol springs in Spania Dolina (Herčko et al., 2014).

Earl A.F. Marsigli, a member of the Paris, London and Montpelier Royal Societies, visited Spania Dolina in 1696 and turned his attention to the cementation waters.

Another notable visitor to Spania Dolina was medical doctor F.E. Bruckmann, in 1724. He was a member of the 
Imperial Academy of Natural Curiosities as well as the Royal Prussian Academy.

During Dr. Bruckmann's visit to Spania Dolina, approximately 4,000 cents of copper from the copper ore and 20 to 24 respectively cents of cementation copper was extracted.

In the mine, at the depth of 70 'siaha' (old measure of length), the cementation water was collected in a small closed area. In a few months, several cents of iron bars were transformed into copper by precipitation. The copper particles accumulated in the water in the place of the iron precipitate Crocus Martis and were transformed into a copper, usually called cementation or pure copper. This transformation occurred more rapidly in different conditions, often in a period of 30 days. The longer period, of several months, was due to suboptimal conditions in one of the springs.

The miners would sometimes place iron items, like horseshoes or nails, in the water to become covered by copper, as mentioned by Bruckmann. These were given as gifts to collectors of curiosities and became a part of some collections of natural history.

On the surface of the mine, a green soil called 'mountain green' or 'shale copper' (Chrysocolla natica, viride montanum) was collected in wooden bins. Bruckmann had never seen this substance before, as it appeared only in association with rich copper veins in Slovakia. Painters used it as a green pigment.

Once the adequate amount of sediment was collected, bins were cleaned and the soil sorted into three grades. The first was captured in the first bin, when water passed through. It was raw, coarse and mixed with sand. The material in the next bin was somewhat smoother, and the third one was the finest, captured in the bins at the end of the water's flow.

In the second edition of the Brückmann work Magnalia dei in locis subterraneis issued at Wolfenbüttel, in 1730, there are other data taken of Probier - Büchlein from an unknown author, who observed the Spania Dolina' mine through a drainage tunnel and its transport to the Ferdinand shaft and then to the eight cementation devices. The capacity of all trenches was as much as 100 cents, and in the largest one it was possible to place 50 cents of iron. The iron which was placed was made up of pistons, pipes, locks, pickers and other mining iron unfit for use. Obtained pure copper was extracted after one year, depending on the difference of iron subjects. Then, it was sent to the Chamber Court in Banská Bystrica and from there, to their new smelter house.

The German polymath J.J. Keyssler also visited the Špania Dolina' mines in the year 1730 and explained the situation of the mine's springs in this way, that vitriol water is nothing more, than just soluble copper, in which iron decays, and instead of iron sediment, particles of copper appear.

\section{The characteristics of copper ore at the Smolnik and Spania Dolina deposits}

Smolnik copper ore contains a good deal of pyrite - on average $6-8 \% \mathrm{Cu}$, from which poor ore contains from $2 \%$ to $3 \% \mathrm{Cu}$, and the richest one as much as $12 \%$ of $\mathrm{Cu}$ and more.
The amount of silver was for the most part low (Herčko, 2003a; Herčko, 2003b).

The source of Spania Dolina cementation waters was extensive copper deposits with various characteristics of the copper ore:

- chalcopyrite ore (yellow), contain as much as $8-10 \%$ of copper and a neglible amount of the silver;

- tetraedrite ore (black), with variable content of copper (4 $18 \%$ ), silver (25-250 ppm) and few grams of gold in one ton of the ore.

Barren rock was grown by copper ore, so some parts contain only as much as $3-4 \%$ of copper.

\section{Differences of cementation waters from Smolnik and Spania Dolina copper mines}

F.E. Bruckmann pointed out the differences between cementation waters in Spania Dolina and Smolnik, where, compared to Spania Dolina, deposits of copper pyrites settled quickly. During intensive mining, these cementation waters offered more methods of copper acquisition from iron fragments and waste.

Differences between Smolnik's cementation water and that of Spania Dolina have been enumerated as follows:

- While the water from Smolnik corroded iron to sludge and dust, because of vitriol concentration, the iron immersed in the water in Spania Dolina remained intact. This is what allowed such items as crosses and horseshoes to be placed in the water, to be covered with copper and presented as gifts.

- The cementation water in Smolnik was made by machines and also its precipitation was on the ground. It contained a lot of copper particles, if fused with iron. The cementation water in Spania Dolina has been used underground. The cementation water in Smolnik was pumped to the surface by machines and its precipitates appeared on the ground. It contained many copper particles which appeared upon contact with iron. The cementation water in Spania Dolina was exploited underground.

- In Smolnik, as much as 600 cents of iron per year were transformed, while production in Spania Dolina was only 20 to -24 cents respectively, because water in Spania Dolina did not escape in large amounts and in some cases travelled through a barren vein.

- In Smolnik, the precipitation took only one month, while in Spania Dolina iron was submerged for a year for the process to be completed. Miners drank this water during various gastric diseases, simply vomited strongly, which can be attributed the large number of sulfate dissolved in the water, and felt better.

\section{Discussion and conclusion}

The presented method here is applicable in the field of the development of historical mining science, as well as in the area of presentations for both professionals and the general public. The science of historical mining reveals many 
opportunities to better understand events that happened, and that deserve to be examined in more detail. Acquiring new reviews should change conventional opinion on leadership, superiority, originality, authenticity, etc.

These new views can change the stereotypes of the primacy, superiority, etc.

Utilization of non-traditional projection forms for instance on the surface of vapor, together with acoustic synchronization and other effects should increase public interest in

\section{References}

Drebenstedt C., Rybár P., Domaracká L., 2011. Montain tourism in Germany shown on example in Saxony. Acta Geoturistica, 2(2): 60-63.

Herčko I., 2002a. Interest in mineral and thermal waters in Slovakia. In Grecula P., Bartalský J., Cambel B., Herčko I., Kaličiak M., Matula M., Melioris M., Polakovič D., Slavkay M., Sombathy L., Šefara J., History of geology in Slovakia, vol. 1. Bratislava: 28-31.

Herčko I., 2002b. The interest in a miracle cementated water in Špania Dolina and Smolník, In: Grecula P., Bartalský J., Cambel B., Herčko I., Kaličiak M., Matula M., Melioris M., Polakovič D., Slavkay M., Sombathy L., Šefara J., History of geology in Slovakia, vol. 1, Bratislava: 31-38.

Herčko I., 2002c. The science journey of German polymath F.E. Bruckmann. In: Grecula P., Bartalský J., Cambel B., Herčko I., Kaličiak M., Matula M., Melioris M., Polakovič D., Slavkay M., Sombathy L., Šefara J., History of geology in Slovakia, vol. 1, Bratislava: 56-58.

Herčko I., 2003a. The miraculous cementated waters of Špania Dolina and Smolník. Copper in Europe, Conferernce Proceedings, 15-17 October 2003, Banska Stiavnica: 69-77. historical mining, which creates a relevant part of the mining heritage of the region, or the bigger part of Europe.

The utilization of presented method in the educational process is an unprecedented positive. Not only because this is interesting as an interactive part of the lecture, but also because there is a possibility to enter to the process of the presentation by students. They should contribute to the final product with knowledge acquired through study at libraries, archives and other sources of the knowledge.

Herčko I., 2003b. Spania Dolina and Lubietovske bearing minerals and the attention of travelers and mineralogists to 1918. Copper in Europe, Conference Proceedings, 15-17 October 2003, Banska Stiavnica: 128-141.

Herčko I., Ambroš P., Hvizdáková J., 2014. Miraculous cementation water in Špania Dolina and Smolník - an underappreciated mining heritage. Acta Geoturistica, 5(1): 47-53.

Hronček P., Kazanský R., Maliniak P., Mičko, P. (eds), 2009. Z dejín vedy a techniky stredoslovenského regiónu. Ústav vedy a výskumu Univerzity Mateja Bela v Banskej Bystrici, Banska Bystrica.

Hvizdák L., 2013. Mining tourism and information technology. Vysoká škola báňská - Technická univerzita Ostrava, Ostrava.

Rybár P., Hvizdák L., 2010. Information technologies and mining tourism. Acta Geoturistica 1(1): 12-24.

Rybár P., Molokáč M., Hvizdák L., Štrba L., Böhm J., 2012. Territory of Eastern Slovakia - area of mining heritage of mediaeval mining. Acta Geoturistica 3(2): 29-35.

Weis K., Nagy M., 2009. Grafické modelovanie pri výskume lomov. In: Hronček P. (ed.), Povrchové relikty po t’ažbe nerastných surovín vo Zvolenskej kotline II. Ústav vedy a výskumu Univerzity Mateja Bela v Banskej Bystrici: 137-143. 